\title{
Surgically induced necrotizing scleritis after primary pterygium surgery with conjunctival autograft
}

This article was published in the following Dove Press journal:

Clinical Ophthalmology

9 November 2011

Number of times this article has been viewed

Katsuya Yamazoe ${ }^{1,2}$

Seika Shimazaki-Den'

Isao Otaka ${ }^{3}$

Kazuki Hotta ${ }^{2}$

Jun Shimazaki ${ }^{1,4}$

'Department of Ophthalmology, Tokyo Dental College, Ichikawa, ${ }^{2}$ Department of Ophthalmology, Kameda Medical Center, Kamogawa, ${ }^{3}$ Yokohama Sotetsu Building Eye Center, Yokohama, ${ }^{4}$ Department of Ophthalmology, Keio University School of Medicine, Tokyo, Japan
Correspondence: Katsuya Yamazoe Department of Ophthalmology, Tokyo Dental College, 5-I I- 13 Sugano, Ichikawa, Chiba, 272-85I 3, Japan

$\mathrm{Tel}+8147322015 \mid$

Fax $+8 \mid 473226786$

Email kyamazoel528@yahoo.co.jp
Background: Although pterygium excision with conjunctival autograft is a widely performed surgical procedure, surgically induced necrotizing scleritis (SINS) following such surgery is extremely rare.

Methods: A 68-year-old man underwent nasal pterygium excision with conjunctival autograft uneventfully. On postoperative day 17, the conjunctival graft was avascular, with epithelial defect. Although topical steroid and antibacterial treatments were continued, the graft and sclera melted, with the ischemic sclera showing gradual thinning. The thinning area spread to the adjoining cornea, and active inflammation with epithelial defect was observed adjacent to the site of thinning.

Results: Systemic and microbiological examination was noncontributory. The patient was suspected of having SINS, and administration of oral prednisolone was started. Although the necrotic area was reduced temporarily, medication was discontinued due to nausea, and the area of thinning increased. Conjunctival flap surgery was later performed, and the graft was well accepted.

Conclusions: SINS must be considered in the differential diagnosis of patients with scleritis following pterygium surgery, especially if radiation or mitomycin $\mathrm{C}$ has not been used.

Keywords: scleritis, pterygium, pterygium surgery, conjunctival autograft, SINS

\section{Introduction}

Surgically induced necrotizing scleritis (SINS), a local autoimmune reaction occurring near previous surgical wounds, has been reported after cataract surgery, trabeculectomy, retinal detachment, and strabismus surgery. ${ }^{1}$ We report SINS after primary pterygium excision with conjunctival autograft, an extremely rare occurrence, with only two previously reported cases., ${ }^{2,3}$

\section{Case report}

A 68-year-old man with no history of systemic or ocular disease was referred to Tokyo Dental College Ichikawa General Hospital for treatment of primary pterygium. Bestcorrected visual acuity (BCVA) was 20/20 in both eyes. Slit-lamp examination revealed nasal pterygium in his right eye, and pterygium excision and conjunctival autograft transplantation without mitomycin $\mathrm{C}$ were performed uneventfully.

On postoperative day 1 , slit-lamp examination revealed a well-adapted, epithelialized graft, with corneal epithelial defect at the site of pterygium excision. Topical treatment with $0.5 \%$ levofloxacin and $0.1 \%$ betamethasone five times daily was initiated. On postoperative day 17, the conjunctival graft was avascular, with epithelial defect; 
the initial corneal epithelial defect had diminished with no symptoms. Although topical steroid and antibacterial agents were continued, the graft and sclera melted, with the ischemic sclera showing gradual thinning. On postoperative day 29, although the scleral bed was covered by keratinized conjunctival epithelium, active inflammation with epithelial defect was observed adjacent to the site of thinning (Figure 1). By postoperative day 36 , the thinning area had spread to the adjoining cornea, and active inflammation persisted. Bacterial and fungal cultures of the lesion were negative. Tests for rheumatoid factor and antinuclear antibody were also negative. A diagnosis of SINS was suspected, and administration of oral prednisolone (20 mg per day) was commenced. Five days later, the conjunctival and scleral inflammation had decreased and vascularization was observed on the inferior scleral side. However, prednisolone was discontinued due to nausea, and the area of thinning increased in size (Figure 2A and B). Resection of necrotic tissue and lamellar keratoplasty were planned but not performed, as the patient ceased visiting the hospital. Conjunctival flap with Tenon's capsule was later performed at another hospital, and the graft was well accepted.

\section{Discussion}

In this case, SINS occurred approximately 2 weeks after surgery, with ischemia of the conjunctival graft and underlying sclera, as previously reported. ${ }^{2,3}$ In earlier cases, the extent of the disease has been limited to the sclera. Here, however, scleral thinning and inflammation spread to the adjoining cornea. Scleral necrosis and melting can occur after pterygium surgery due to the use of adjunctive irradiation, mitomycin $\mathrm{C}$,

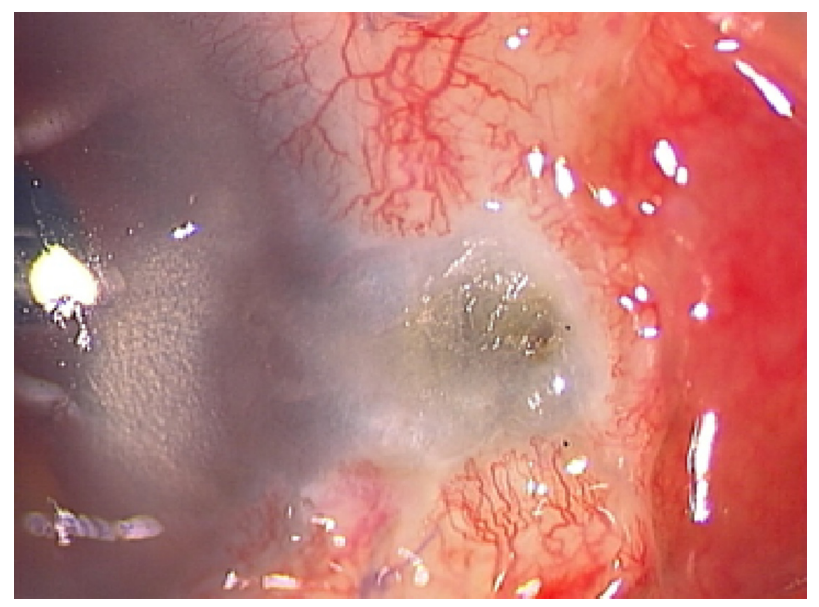

Figure I Slit-lamp photograph of surgically induced necrotizing scleritis on postoperative day 29. Although the scleral bed was covered by keratinized conjunctival epithelium, active inflammation and epithelial defect were observed adjacent to the site of thinning.
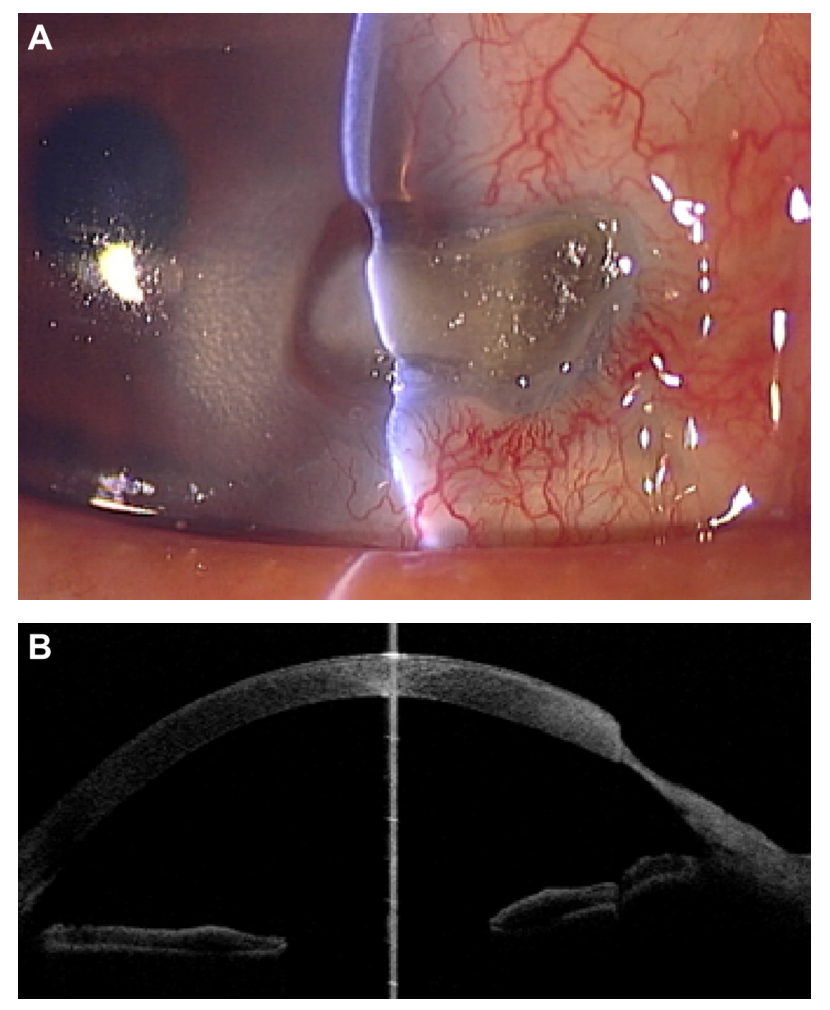

Figure 2 Slit-lamp photograph and anterior optical coherence tomography after discontinuing systemic steroid treatment. (A) Scleral and corneal bed at the site of pterygium excision showing substantial thinning and active surrounding conjunctival inflammation. (B) Anterior optical coherence tomography also showed major corneoscleral thinning.

or excessive cauterization of the sclera. ${ }^{4-6}$ These etiologies should be ruled out before diagnosing SINS. In this case, no radiation or mitomycin $\mathrm{C}$ was used, and cauterization was kept to a minimum during surgery. In fact, hundreds of pterygium surgeries have been performed at our institute, in the same manner, with no other cases developing necrotizing scleritis. The spread of the disease to the cornea eliminated cauterization as a likely primary cause. In addition, reduced inflammation after systemic immunosuppression supported our diagnosis, indicating the utility of immunosuppressive treatment in identifying SINS.

Treatment of SINS after pterygium surgery has included immunosuppression with systemic steroids, cyclophosphamide, or tacrolimus, ${ }^{2,3,7,8}$ and surgical intervention, including resection of necrotic tissue, amniotic membrane transplantation, and scleral or corneal tissue patch grafts. ${ }^{2,7,9,10}$ In this case, systemic steroids had to be discontinued, and the administration of tacrolimus and further surgical procedures were considered. Conjunctival flap with Tenon's capsule is an option, especially if obtaining a scleral or corneal graft is difficult. Resection of necrotic tissue and conjunctival flap with Tenon's capsule were performed, and the graft was well accepted. 
This case suggests that SINS should be considered as a possible diagnosis in patients with scleritis after pterygium surgery, especially if radiation or mitomycin $\mathrm{C}$ has not been used. Ischemia and melting in the conjunctival graft and underlying sclera indicate SINS, and a risk exists of it spreading to the adjoining cornea.

\section{Disclosure}

The authors report no conflicts of interest in this work.

\section{References}

1. O'Donoghue E, Lightman S, Tuft S, Watson P. Surgically induced necrotizing sclerokeratitis (SINS) - precipitating factors and response to treatment. Br J Ophthalmol. 1992;76:17-21.

2. Jain V, Shome D, Natarajan S, Narverkar R. Surgically induced necrotizing scleritis after pterygium surgery with conjunctival autograft. Cornea. 2008;27:720-721.

3. Sridhar MS, Bansal AK, Rao GN. Surgically induced necrotizing scleritis after pterygium excision and conjunctival autograft. Cornea. 2002;21:305-307.

4. MacKenzie FD, Hirst LW, Kynaston B, Bain C. Recurrence rate and complications after beta irradiation for pterygia. Ophthalmology. 1991;98:1776-1780; discussion 1781.
5. Rubinfeld RS, Pfister RR, Stein RM, et al. Serious complications of topical mitomycin-C after pterygium surgery. Ophthalmology. 1992;99:1647-1654.

6. Alsagoff Z, Tan DT, Chee SP. Necrotising scleritis after bare sclera excision of pterygium. Br J Ophthalmol. 2000;84:1050-1052.

7. Young AL, Wong SM, Leung AT, Leung GY, Cheng LL, Lam DS Successful treatment of surgically induced necrotizing scleritis with tacrolimus. Clin Experiment Ophthalmol. 2005;33:98-99.

8. Vagefi MR, Hollander DA, Seitzman GD, Margolis TP. Bilateral surgically induced necrotizing scleritis with secondary superinfection. $\mathrm{Br} \mathrm{J}$ Ophthalmol. 2005;89:124-125.

9. Karalezli A, Kucukerdonmez C, Borazan M, Akova YA. Successful treatment of necrotizing scleritis after conjunctival autografting for pterygium with amniotic membrane transplantation. Orbit. 2010;29:89-90.

10. Ti SE, Tan DT. Tectonic corneal lamellar grafting for severe scleral melting after pterygium surgery. Ophthalmology. 2003;110:1126-1136.
Clinical Ophthalmology

\section{Publish your work in this journal}

Clinical Ophthalmology is an international, peer-reviewed journal covering all subspecialties within ophthalmology. Key topics include: Optometry; Visual science; Pharmacology and drug therapy in eye diseases; Basic Sciences; Primary and Secondary eye care; Patient Safety and Quality of Care Improvements. This journal is indexed on

Submit your manuscript here: http://www.dovepress.com/clinical-ophthalmology-journal

\section{Dovepress}

PubMed Central and CAS, and is the official journal of The Society of Clinical Ophthalmology (SCO). The manuscript management system is completely online and includes a very quick and fair peer-review system, which is all easy to use. Visit http://www.dovepress.com/ testimonials.php to read real quotes from published authors. 